\title{
Being a trainer in the French vocational training system: a case study of job status and working conditions in relation to perceived health
}

\author{
Catherine Delgoulet ${ }^{a b^{*}}$ \\ ${ }^{a}$ LATI, Université Paris Descartes, Sorbonne Paris Cité, Institut de psychologie, 71 avenue Edouard Vaillant, 92 \\ 000 Boulogne-Billancourt, FRANCE \\ ${ }^{\mathrm{b}}$ CREAPT, Centre d'Etude de l'Emploi, 29 promenade Michel Simon, 93 Noisy-le-Grand cedex, FRANCE
}

\begin{abstract}
This communication presents part of an international project focused on the work of trainers from an ergonomics perspective. The objective is to identify in the French vocational training system the various types of job status of trainers and their impact on working conditions and health. In order to explore this issue, we met with 11 trainers, all volunteers, working in the music or human resources sectors. Semi-structured interviews and transcriptions of two weeks of the trainers' professional schedules form the data collected. The analyses show that trainers have various job statuses as trainers and sometimes hold down several jobs at the same time. These working situations create freedom but lack security. With very long daily or weekly working hours, the relationships with trainees and clients are qualified as both very interesting, but also one of the most difficult aspects of the work. The 11 trainers, who considered themselves to be in good health, do however declare infrapathological disorders, which they often relate to their working conditions. These findings are discussed with regard to the literature and raise issues relating to ergonomic methods in activity analysis and situated action.
\end{abstract}

Keywords: trainers, activity, working conditions, job status, perceived health

\section{Introduction}

This work is part of a broader research project that associated French Canadian, Portuguese and French researchers for many years (Céline Chatigny Université du Québec in Montréal, Marta Santos Université de Porto, Catherine Delgoulet Université Paris Descartes and Hélène Veyrac ENFA). This paper presents the first results collected in France during two case studies.

\subsection{The overall objective}

The project took place in a social and scientific context summarized in 3 points:
- trainers said they have to deal with major difficulties in their day-to-day practice (e.g. vocational integration, skills transfer, intellectual development, job status), and also have to manage fatigue and stress;

- the dropout rate in the first years of work was particularly high in Quebec [1];

- sociological studies of trainers' job(s) were carried out which focused on identifying the trainers' functions or professional identities [2]; but less scientific research has been carried out on trainers' real working conditions and their potential impact on health.

\footnotetext{
*Corresponding author. E-mail: catherine.delgoulet@parisdescartes.fr.
} 
The overall objective was to develop theoretical and methodological tools that could be used to build up scientific knowledge of trainers' jobs and to improve their training and working conditions.

\subsection{French context and issues}

In France, the number of people at work who considered themselves as "trainers" has been continuously growing since the 1980 's, although the scope of this occupation is still not clearly defined, either in terms of the qualifications required, nor the tasks they accomplish. Statistics from two national surveys (the population census and the "employment survey") highlighted the increase in trainer vocations but also showed a differential of $32 \%$, which confirmed the vagueness of this situation [3].

Recently, the analyses carried out on salaried trainers participating in the SUMER 2003 survey [4] showed that trainers were exposed to specific physical and organizational constraints.

Three types of physical constraints characterized the job: visual constraints $(63.4 \%$, including $56.2 \%$ for screen exposure), postural and skeletal constraints (59.3\% remain standing for several hours) and driving constraints $(46.6 \%)$. In comparison with the overall survey population $(49,984$ people), trainers declared that they were more exposed to visual constraints and driving obligations. Finally, even if they were proportionally less exposed to postural and skeletal constraints than employees as a whole, more than half mentioned them as a feature of their work.

Moreover, trainers also quoted three organizational constraints:

- Contact with the public $(94.5 \%)$, strongly related to the risk of verbal altercations $(73.1 \%)$ and, to a lesser extent, to physical risks (41.5\%);

- The variability of work schedules from one week to the next $(80.8 \%)$, or one day to the next $(35.2 \%)$, related to working from home $(27 \%)$;

- Tasks and their organization linked to external requests $(57.4 \%)$, without always having the means for dealing with them (material means $25.7 \%$; information $25 \%$; lack of training $24.5 \%)$.

Trainers seemed to be more exposed to verbal and physical altercations than the survey population, and also to contact with the public, variable work schedules (weeks, days, unpaid overtime) and the lack of means.
To sum up, in France the work of trainers is not defined at all and some aspects remain very unclear. However, the work constraints can partly be defined as typical of jobs in the service sector (contact with the public and dependency on external requests) in that they are psychologically demanding [5], and that in addition there is an increased risk of physical or verbal altercations.

The facts established allowed us to suggest the existence of a possible link between the aforementioned difficulties faced by trainers and specific working conditions. Moreover, ergonomists [6][7][8][9] took an interest in the work of teachers and trainers and especially in what happens in the classroom. We suggested broadening the scope to take into account other aspects of work, outside of the classroom $[10][11][12]$ that we did not find to be defined in the literature.

In this context, our objective was to identify how the job and the physical, material or organizational working conditions manifest themselves in real working situations, and to identify the impact they have on task achievement, and the possibilities for skills development and the preservation of trainers' health.

\section{Methods}

This exploratory work was the accumulation of two case studies carried out simultaneously with volunteer trainers working in two training centers: one training professional musicians and the other for managers in the human resources sector.

\subsection{The trainers}

Five women and six men formed the sample of 11 trainers (six in music or lyrics; five in corporate law or human resources). They were aged between 24 to 52 years old and had between 1 and 25 years' experience, as a trainer. Their initial training was equal to or higher than the baccalaureate. They added complementary training throughout their career as a musician or HR manager's. None had a specific trainer diploma (in France there are no specific diplomas for working as a trainer in the vocational training system), just one of them was qualified as the manager of a training organization.

This population was composed of two contrasting subgroups: the music trainers were generally young and male (aged between 24 to 36 years; five men and one woman); the human resources trainers were gen- 
erally older and female (43-52 years old; four women and one man).

\subsection{Data collation and analyses}

Semi-structured interviews were conducted with all trainers following a guide developed as part of the overall project framework. It contained questions regarding: the trainers' socio-demographic characteristics, their educational and professional background, their reasons for becoming trainer, the tasks and their degree of difficulty or simplicity, the description of each trainer's working week, social support, material resources and finally their perceived health.

Records were kept of the trainers' diaries or activity schedules. They allowed us to identify the tasks, their scope and their distribution over the days and weeks.

Two types of analyses were carried out:

- The first was a quantitative analysis to characterize the population (qualification, employment status, health and diseases, etc.), and estimated its formal and informal work;

- The other was a qualitative analysis, to piece together elements of their professional careers and reconstruct the organization of their weeks. These analyses were carried out using Kronos software [13].

\section{Results}

\subsection{The diversity of careers and the trainers' current status}

The career analysis showed that there were a variety of ways of becoming a trainer. For example (figure 1), TM1 became trainer just after he finished his higher education aged 23 years. Since this date, he has worked as a trainer. Conversely, THr11 finished his education earlier and had two jobs (factory and then office worker) before becoming a trainer.

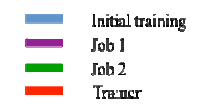

TMI (Music treiner)

TH:ll (Hunan resources trainer)

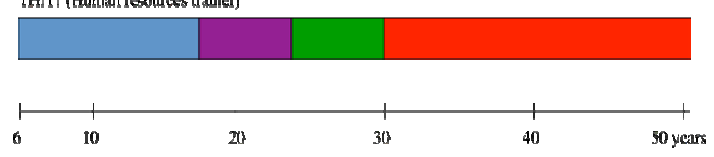

Figure 1: Two examples of trainer career reconstitutions; Music Trainer $\mathrm{n}^{\circ} 1$ (TM1) and Human resources Trainer $\mathrm{n}^{\circ} 11(\mathrm{TH} 11)$.

The results showed that music trainers had no or little professional experience before becoming trainers, compared to Human Resources trainers who had one, two or three previous professional experiences.

In our sample, people explained they became trainers for six types of reasons. The main reasons cited were: "an interest in transmission", "possibility for career change whilst remaining in the same field", "professional opportunities" and "the pursuit of professional stability". "Private life" or "health" reasons were also cited but less frequently (Table 1).

Table 1

The reasons for becoming a trainer cited by trainers and the frequency with which they were mentioned.

\begin{tabular}{|l|l|}
\hline Reasons for becoming a trainer & Frequency \\
\hline Interest in transmission & 4 \\
\hline Career change within the same field & 3 \\
\hline Professional opportunities and networking & 3 \\
\hline The pursuit of professional stability & 3 \\
\hline Private life reasons & 2 \\
\hline Health reasons & 1 \\
\hline
\end{tabular}

There were seven types of employment status: employee status (never full time), part-time lecturer, working for an umbrella company, independent worker, intermittent du spectacle (status specific to France) and illegal. The majority worked under employee status (7/11; figure 2). Most of them (8/11) had two or three types of employment status for positions held simultaneously. 


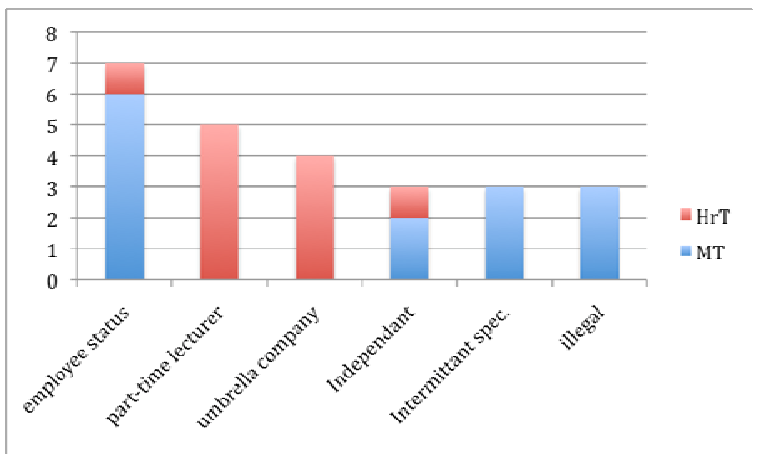

Figure 2: Job status distribution of the 11 trainers interviewed

Whereas Human Resources trainers did not declared any other professional activity, the music trainers were characterized by the number of jobs held simultaneously in a variety of sectors: concert artists, hostesses, builder's helper. At most they held three jobs simultaneously (e.g. trainer, concert artist and blue collar worker). Other jobs represented $0 \%$ to $75 \%$ of the weekly duration of work.

\subsection{Long working weeks}

Rather than diversity in terms of jobs and activities, certain similarities emerged. The analysis of the trainers' schedules showed that, trainers worked few hours per week for one training center (3 to 21 hours; Mean Duration 11 hours). However, they had long working weeks ( 33 to $63 \mathrm{hrs} /$ week; $\mathrm{MD}=42 \mathrm{hrs} /$ week) and they sometimes worked long working days (15hrs/day).

Trainers identified 15 tasks they had to accomplish at work and we divided these into 8 categories (Figure 3). Only two of them were mentioned by all the participants: teaching classes, and preparing classes. Human resources trainers identified some tasks that music trainers did not. We categorized them as three types: consultancy and business, pedagogical engineering, and development activities (writing articles, conferences) considered as a way of promoting their training business.

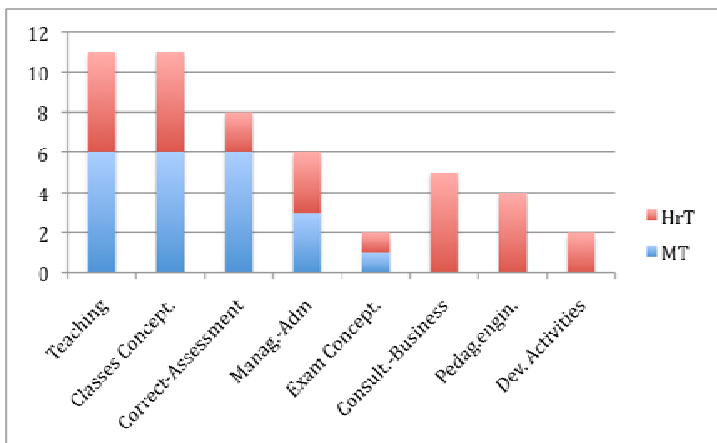

Figure 3: Common tasks for trainers and and number of mentions

What trainers appreciated most about their work was the transmission of knowledge and the opportunity to share their interest or passion for the field in which they train; they also liked the social contact and relationships. Trainers also mentioned their contribution to trainees' personal and career development, the diversity of situations and populations encountered, and the development of pedagogical methods (figure 4).

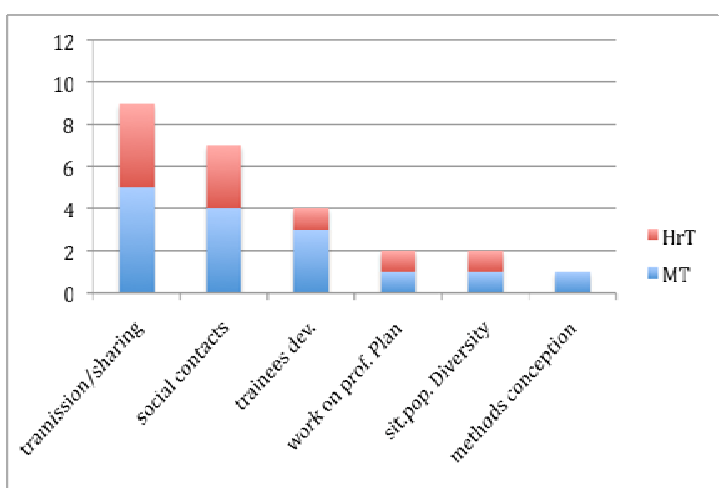

Figure 4: Job interests mentioned by trainers.

At the same time, trainers considered social relationships with trainees and clients as a major difficulty (9/11): when trainees were "demotivated" or when there were a lot of intermediaries between them and their clients. Some of them also mentioned physical or technical and organizational constraints (at work and at home). Human resources trainers mentioned 5 further difficulties: business trips, lack of job security, financial constraints, the lack of collective work and continuous updating (figure 5). 


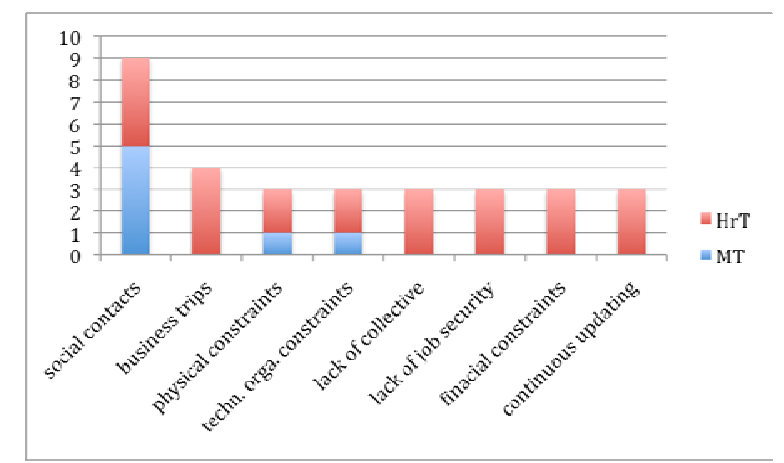

Figure 5: Job difficulties mentioned by trainers

\subsection{Some health disorders}

Although the trainers said they did not suffer from health disorders $(9 / 11)$, they talked about various infra-pathological disorders (fatigue; difficulties sleeping; stress; physical exhaustion; hearing impairments; musculo-skeletal disorders; figure 6). They partly related them to their work conditions.

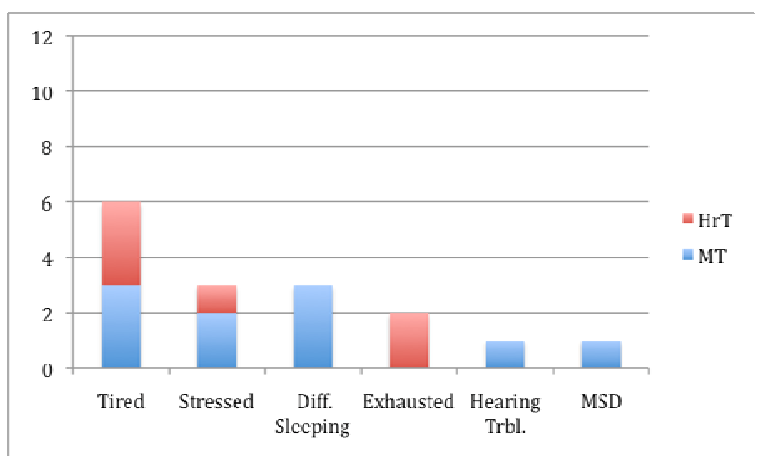

Figure 6: Disorders declared by trainers.

Four declared one disorder, six declared two or three disorders, and only one declare no disorders. Music trainers had proportionally more disorders than Human Resources trainers (the means were 1.66 and 1.2 respectively). Two Human Resources trainers talked about two other diseases that they did not relate to their working conditions (sleep apnea with narcolepsy and organ prolapse). However, these disorders complicate their work.

When they associated the disorders to working conditions they mentioned:

- paying attention during classes, the intensive rhythm of classes, lack of sleep, constantly updating the training course content doing several different jobs simultaneously, managing family life and the increasing density of training (fa- tigue and stress); For example, one trainer said: "Fatigue and stress, it is the everyday life of all trainers" [TM2];

- long working day (difficulties sleeping): "I am not very well because of my lack of sleep. For example, I played yesterday evening. I got home at half past two in the morning, and went to sleep an hour later. I woke up at 8 o'clock this morning... I have to consult a doctor every month for that" [TM6];

- the strain of business trips, uncertain work patterns, standing, carrying and playing musical instrument (exhaustion, hearing disorders, illness and MSD); Another trainer noted that the intensity of teaching had an impact on her health: "I am generally ill after 5 days of training. In my opinion, this is a job where we suffer. It is very difficult to run classes everyday. Physically, it is difficult" [THr8].

\section{Discussion-conclusion}

Contrary to the commonly held belief in France that people become trainers in the middle of their career, after specific professional experience, the results showed that work constitutes a stage in a person's career which in the HR sector comes at the end of a career and in the music sector at the beginning. The reasons for becoming a trainer were diverse (the interest in transmission, career change within the same field, networking, desire for professional stability etc.). The interest in transmission, also often believed to be the determining factor in terms of the trainer's career decision, was only cited by 4 trainers out of 11. We noticed similarities with Cardon's study [14], which described trainers' careers as "different paths" along which the period as a trainer sometime began at the end of initial education and sometime later. However, people began often to practice musical instrument when they were young. This fact means these young trainers effectively had an artistic career in contradiction with Cardon's results.

In our sample, we noticed a wide variety of employment statuses, although most were part-time employees. On one hand this diversity of statuses means there is greater freedom in terms of how people become trainers. On the other hand it could also be a sign of social and economic fragility. In the music trainer subsample, the accumulated statuses were always accompanied by simultaneous jobs (concert artist, hostess or builder's helper). The hypothesis of 
economic fragility was strengthened here: this fragility obliged trainers to manage several professional activities simultaneously. The HR trainers, for their part, mentioned the lack of job security as one of the difficulties of the job, with financial and organizational consequences.

The diversity in careers, reasons for choosing this work and employment statuses, could be explain the "fragmentation" of the trainer population as expounded in sociology [15], which seems to be unfavorable to the development of a professional identity [2]. Beyond the issue of professional identity, we suggest that the overlap of jobs and tasks should be thought about in relation to the time ratio and the impact on health.

Like the SUMER Survey [4], we found some organizational constraints, which are characteristic of service activities. In the two cases studied, constraints related to contact with the public were cited. They were considered both in a positive way (taking pleasure in passing on knowledge, sharing with trainees, supporting them in their growth) and in a negative way (when relationships with trainees or companies were perceived as difficult), but never associated with a risk of a physical altercation as in the survey. The uncertain work patterns (related to external demands), the variability from one week to the next, associated with long working days in vocational training and at home or in travel, were also mentioned. However, the physical constraints found in SUMER (visual constraints due to work on screen, postural constraints related to remaining standing during training sessions and driving constraints because of the number of trips) did not appear in the situations studied. We even noted that HR trainers, who worked for several companies and institutions, identified other constraints relating to business trips in France or abroad. These were not driving constraints because they traveled by train or plane, but the strain of travel (waking up early in the morning to reach the training location, finishing late, sleeping in hotels, even jet lag etc.).

Obviously, the impact on working conditions was not univocal [5]. Trainers said they appreciated the relationships built up at work during the training sessions, negotiations with clients and the sharing activities and transmissions. At the same time, they dreaded these relationships and although most of them considered themselves to be in good health, only one trainer did not mention any infrapathological disorders. Trainers systematically made the link between their disorders and working conditions, notably lack of job security and associated uncertainty, simultane- ous jobs, work intensification (shorter and shorter training sessions to cover the same content), organizational difficulties and irregular work patterns, the intensity of face-to-face pedagogical activities (maintaining attention and keeping interest throughout the training course), etc. This situation was worrying in so for as it was the youngest trainers (music) who declare the most disorders and who most often make this link with working conditions.

These results, based on two case studies, do not claim to be exhaustive. Nevertheless, they highlighted some particularities that should be taken into account when analyzing trainers' work. Because of the diversity and plurality of employment statuses, we had to integrate numerous factors into the methodological approach: for example, the nature and level of initial education, the field of professional training and its working specificities, the trainer's age, the stage in the career at which the person became a trainer. Although this does not address all the issues related to the work of trainers', it shows the fragility of methods only based on interviews and professional schedules in which some aspects of the investigation remained very unclear. Some research has pointed out the difficulties ergonomists have in taking into account the trainer's work and their working conditions as a whole. It has highlighted the challenges facing ergonomists looking to build new methodological tools for describing the activity of trainers [16]. There is also a further difficulty related to the increase in the accumulation of work situations, jobs and employers. Ergonomists today are not sufficiently equipped to deal with these issues but they have to think about them, especially if, as suggested Menger [17], the "artistic" context (defined by autonomy, flexibility and lack of job security) is becoming more generalized and variations of this situation are found in other professional sectors, indeed it seems to have become the "worker" context in an undifferentiated manner. The isolation due to "independent worker" status (or similar) accentuated the fragmentary nature of this job and added to the difficulty of activity analysis, and the difficulties in terms of interventions in situ. Due to the infrapathological disorders identified in the sample of trainers, we now have two issues to address in order to make improvements in the future. 


\section{Acknowledgement}

I would like to thank Ilannah Alimi and Délaram Zandieh who took part in the data collation.

I express my deep gratitude to Dominique CauBareille and Céline Chatigny who read the first version of the text and made suggestions for improvements.

\section{References}

[1] M. Tardif, Quelques indicateurs de l'attrition des nouveaux enseignants de la formation professionnelle au Québec. In La recherche en éducation et le développement de la pratique professionnelle en enseignement. A. Beauchesne, S. Martineau and M. Tardif, Eds., Éditions du CRP, Université de Sherbrooke, 2001, pp. 131-141.

[2] E. Lescure (de) and C. Frétigné, eds. Les métiers de la formation. Approches sociologiques, PUR, Mayenne, 2010.

[3] F. Lebon, and E. Lescure (de), "Nouvelles professions" et fermeture des marchés du travail: le cas des animateurs socioculturel et des formateurs d'adultes (1982-2002). 2ème congrès de 1'Association Française de Sociologie, 2006, 5-8 septembre, Bordeaux.

[4] B. Arnaudo, M.-C. Floury, N. Guignon, I. Magnuad-Camus, N Sandret, L. Vinck and D. Waltisberger, Les expositions aux risques professionnels par famille professionnelle. Résultats SUMER 2003. Documents d'études DARES, 2006.

[5] M. Gollac and S. Volkoff, Les conditions de travail. La Découverte, Paris 2007.

[6] K. Messing an A.M. Seifert, A.M. «On est là toutes seules». Contraintes et stratégies des femmes en contrat à durée déterminé dans l'enseignement des adultes, Travailler 7 (2001), 147-166.

[7] J. Rogalski, Y a-t-il un pilote dans la classe ? Une analyse de l'activité de l'enseignant comme gestion d'un environnement dynamique ouvert, Recherches en didactique des mathématiques 23 (2003), 343-388.

[8] J. Riel and K. Messing, Counting the minutes: Administrative control of work schedules and time management of secondary school teachers in Québec, WORK (in press).

[9] H. Veyrac and N. Asloum, Les tâches appropriées des professeurs de l'enseignement professionnel. Illustration du hiatus enre le travail en entreprise et la formation, Activités, 6 (2009), 69-86. http://www.activites.org/v6n1/v6n1.pdf

[10]C. Chatigny, training while training: the challenge of vocational training teachers, proceedings of the IEA congress, 2009, the 9-14th of August, Beijing (China).

[11]M. Santos, S. Gomes, and M. Lacomblez, Les conditions de travail et de santé des formateurs en formation professionnelle : Observations relatives au cas portugais, Séminaire Université de Porto/Université de Paris Descartes, 2009, 29 mai, Paris.

[12]D. Cau-Bareille. Factors influencing early retirement in a female-dominated profession: Kindergarten teacher in France "), Work, in press.

[13] A. Kerguelen, “Actogram Kronos" : un outil d'aide à l'analyse de l'activité. In Les techniques d'observation en sciences humaines, H. Norimatsu and N. Pigem, Eds., Armand Colin, Paris, 2008, pp. 142-158.

[14]C.A. Cardon, Devenir formateur d'adultes. Des itinéraires pluriels, des logiques sociales spécifiques. Formation Emploi, 63 (1998), 5-22.

[15]P. Gravé, Formateurs et identité. L'identité professionnelle des formateurs d'adultes et son analyse. PUF, Paris, 2002

[16]C. Chatigny, and N. Vézina, L'analyse ergonomique de l'activité de travail: un outil pour développer des dispositifs de formation et d'enseignement. In Didactique professionnelle et didactique disciplinaire en débat, Y. Lenoir and P. Pastré, eds., Octarès, Toulouse, 2008, pp. 126-147.

[17]P.M. Menger, Portrait de l'artiste en travailleur: métamorphose du capitalisme. Seuil, Paris, 2003 